\title{
Comparative efficacy of biologics as monotherapy and in combination with methotrexate on patient reported outcomes (PROs) in rheumatoid arthritis patients with an inadequate response to conventional DMARDs - a systematic review and network meta-analysis
}

Jeroen P Jansen ${ }^{1,2}$, Felicity Buckley ${ }^{3^{*}}$, Fred Dejonckheere ${ }^{4}$ and Sarika Ogale ${ }^{5}$

\begin{abstract}
Objective: To compare biologics as monotherapy or in combination with methotrexate (MTX) in terms of patient reported outcomes (PROs) in RA patients with an inadequate response to conventional DMARDs (DMARD-IR).

Methods: With a systematic literature review 17 RCTs were identified that evaluated adalimumab, certolizumab pegol, etanercept, golimumab, infliximab, abatacept, anakinra or tocilizumab. Treatment effects in terms of pain (0-100 mm), patient's global assessment of disease activity (PGA; 0-100 mm), Health Assessment-Questionnaire (HAQ) disability index ( $\mathrm{Dl} ; 0-3)$, and the physical component summary (PCS) of the SF36 Health Survey (0-100) at 24 weeks were combined by means of Bayesian network meta-analyses.
\end{abstract}

Results: With tocilizumab monotherapy, greater improvements in pain (difference $=-11.1$; (95\% Credible Interval $-21.3,-0.1))$ and PGA $(-10.3(-20.4,0.8))$ were observed than with aTNF monotherapy. Tocilizumab was at least as efficacious as aTNF in HAQ-DI improvements $(-0.16 ;(-0.37,0.05))$. aTNF + MTX $(-17.9(-23.1,-13.0) \&-19.1$ $(-24.2,-14.4))$, abatacept + MTX $(-23.0(-47.3,1.5) \&-13.6(-28.4,2.0))$ and tocilizumab + MTX $(-16.0(-26.3,-6.3)$ \& -15.1 (-25.1, -5.7)) showed comparable reductions in pain and PGA relative to MTX. Efficacy of anakinra + MTX was much smaller as compared to other biologics. The greatest improvements in HAQ-DI relative to MTX were observed with aTNF + MTX $(-0.30(-0.37,-0.22))$ and tocilizumab + MTX $(-0.27(-0.42,-0.12))$, followed by abatacept + MTX $(-0.21(-0.37,-0.05))$ and anakinra + MTX $(-0.11(-0.26,0.05))$. The improvements in SF36-PCS with abatacept + MTX, aTNF + MTX and tocilizumab + MTX were comparable. There is a $>90 \%$ probability that aTNF + MTX results in a greater improvement in pain (-12.4), PGA (-16.1) and HAQ-DI (-0.21) than aTNF as monotherapy. Efficacy of tocilizumab + MTX showed comparable improvements in PROs as tocilizumab monotherapy.

Conclusions: Based on a network meta-analysis involving indirect comparison of trial findings, the following observations were made for DMARD-IR patients. In monotherapy, tocilizumab was associated with a greater improvement in pain and self-reported disease activity than aTNF, and was at least as efficacious regarding functional ability. The improvements in PROs with aTNF, abatacept and tocilizumab in combination with MTX were comparable. Improvements in PROs with tocilizumab as monotherapy were similar to that of tocilizumab + MTX, whereas aTNF as monotherapy was likely to be less efficacious than aTNF + MTX.

Keywords: Rheumatoid arthritis, Biologics, Patient reported outcomes, Network meta-analysis, Indirect comparison

* Correspondence: fbuckley@mapigroup.com

${ }^{3}$ Mapi Group, 180 Canal Street, Suite 503, Boston, MA 02114, USA

Full list of author information is available at the end of the article 


\section{Background}

Rheumatoid arthritis (RA) is a chronic inflammatory joint disorder characterised by joint stiffness, swelling, and pain, and can have a profound impact on a patient's health related quality of life $[1,2]$. As such, the goals of treatment of RA are not only symptom relief, reduction in disease activity, and reduction in the rate of joint damage, but also improvement in physical functioning and well-being from the patient's perspective $[3,4]$.

The European League Against Rheumatism (EULAR), American College of Rheumatology (ACR), and Outcomes Measures in Rheumatology (OMERACT) have outlined the importance of patient reported outcomes (PROs) in addition to physician assessed outcomes for the complete assessment of progression of disease and the evaluation of the effectiveness of RA treatment [5]. PROs used for the assessment of treatments in RA clinical trials typically include pain, patient's global assessment of disease activity (PGA), and the general health measures Health Assessment-Questionnaire (HAQ) disability index (DI) and Medical Outcomes Study Short Form 36 Health Survey (SF36) [6-8].

Patients who are intolerant or show an inadequate response (IR) to traditional disease-modifying antirheumatic drugs (DMARDs) are often treated with a biologic agent. For DMARD-IR patients, biologics are usually combined with traditional DMARDs, primarily methotrexate (MTX), but some biologics are approved and have been shown to be efficacious as monotherapy as well [9-11]. In real life, approximately one-third of RA patients on biologics are on monotherapy [12-14].

Given the number of the alternative biologic treatment options for the DMARD-IR RA population, clinicians are faced with a challenging choice regarding the optimal treatment. There is no randomized controlled trial (RCT) that evaluates all approved biologics simultaneously to help answer this question. The available evidence base consists of multiple placebo controlled trials and some active head-to-head comparisons. Network meta-analysis has been introduced, as a generalisation of pair-wise meta-analysis, to simultaneously synthesize the different RCTs evaluating different biologics and perform indirect comparisons in the absence of head-to-head studies. In the past few years several network meta-analysis of biologic treatments for RA have been published [15-22]. However, currently there is no network meta-analysis that compares the treatment effects of combination therapy and monotherapy regarding PROs.

The objective of the current study was to compare the efficacy of biologic DMARDs used as monotherapy or in combination with MTX in terms of pain, self-reported disease activity, functional ability, and overall health related Quality of Life (HRQoL) among DMARD-IR RA patients based on currently available evidence from RCTs.

\section{Methods}

Identification and selection of studies and data extraction

The following criteria for considering published studies for review were used:

- Population of interest: DMARD-IR RA patients.

- Interventions: tocilizumab, TNF-blockers, abatacept, and anakinra in their usual dose, alone and in combination with conventional DMARDs. Rituximab was not considered because its label is restricted to TNF-IR patients. Tofacitinib was not included because it was not approved at the time of this study.

- Comparisons: Placebo or one of the regimes described under interventions. Comparisons of different dosages of the same intervention only, or comparison of the same interventions with different background treatments were excluded.

- Outcomes/endpoints: HAQ-DI, Pain, PGA, SF36, and fatigue.

- Study design: randomized controlled trials

- Exclusion: Studies with solely Asian patients, and non-English language publications were excluded.

The pre-defined search strategy of the Medline, Embase, and Cochrane databases used terms related to RA, biologics, and RCTs to allow for a systematic search of studies published between 1990 and April 2012 (See Appendix for search strategy). Titles and abstracts were screened to ascertain whether studies met predefined selection criteria. Studies that either met the criteria or for which it was unclear were further screened using the full text report.

For each identified study that met the selection criteria, details were extracted on study design, study population characteristics, study quality according to the Jadad criteria [23], interventions, and the outcomes pain, PGA, HAQ-DI, and SF36. Pain and PGA were assessed on 0 to $100 \mathrm{~mm}$ visual analog scale (VAS); higher scores reflect greater pain and disease activity and minimum clinically important differences (MCIDs) are $\geq 10 \mathrm{~mm}$ increase from baseline [24-28]. HAQ-DI assesses the level of an individual's functional ability and scores range from 0 to 3 ; higher scores indicate more severe disability and the MCID is a $\geq 0.22$ points increase [25]. The SF36 yields 8 domain scores which are summarized in a physical health component summary (PCS) score and mental health component summary (MCS) score. The scale ranges from 0 to 100 with higher scores reflecting greater HRQoL. Improvements of $\geq 5$ points from baseline represent a MCID [7,8].

\section{Network meta-analysis}

To synthesize the results of the included studies, Bayesian network meta-analysis models were used [29-32]. For the 
analysis we grouped the different aTNFs because previous analysis demonstrated that the different aTNFs are exchangeable $[19,20]$. Within a Bayesian framework, analysis involves data, a likelihood distribution, a model with parameters, and prior distributions for these parameters [33]. A regression model with a normal likelihood distribution relates the data from the individual studies to basic parameters reflecting the (pooled) treatment effect of each intervention compared to placebo. Based on these basic parameters, the relative efficacy between each of the compared biologics, as monotherapy and combination was calculated.

Both fixed and random effects models were considered and were compared regarding the goodness-of-fit to the data, calculated as the posterior mean residual deviance. The deviance information criterion (DIC) provides a measure of model fit that penalizes model complexity [34]. The random effects model resulted in the lowest DIC, and was considered appropriate for the synthesis of the available evidence.

To avoid influence of the prior distributions required for the Bayesian analyses on results, non-informative prior distributions were used. Prior distributions of the treatment effects relative to placebo were normal distributions with mean 0 and a variance of 10,000 . A uniform distribution with range of 0-20 (pain, PGA, SF36) and $0-6$ (HAQ) was used for the prior distribution of heterogeneity needed for the random effects analyses. WinBUGS statistical software was used for the analyses [35]. The results of the network meta-analysis provide us with posterior distributions of treatment effects of each treatment versus placebo in terms of difference in change from baseline. In order to transform these difference measures into an expected change from baseline with each treatment, the effect estimates of each regimen relative to placebo were combined with the average change from baseline with placebo across studies. The posterior distributions of the treatment effect (i.e. difference in change from baseline) and expected change from baseline by treatment were summarized with the median and $95 \%$ credible intervals $(95 \% \mathrm{CI})$ reflecting the range of true underlying effects with $95 \%$ probability. Based on the posterior distributions of relative treatment effects the probability that a certain intervention was more efficacious than a competitor was calculated, as well the probability that each treatment ranks $1^{\text {st }}, 2^{\text {nd }}, 3^{\text {rd }}$, etc. The latter findings were expressed with rankograms.

\section{Results}

\section{Study identification}

The literature search resulted in 1,217 unique, potentially relevant citations, of which abstract review excluded 1,060 (87\%) (Figure 1). Of the remaining 157 retrieved full text publications, 133 (11\%) were excluded through the full-text review. A total of 26 full text reports corresponding to 20 different RCTs, including 2 studies provided by Roche (ACT-RAY and ADACTA) met the selection criteria [9-11,36-56]. These 2 latest studies were not published at the time of the data cut, but were considered crucial for the evidence network.

\section{Evidence base}

Most of the trials were multi-centred and included patients predominantly from Europe and North America. The RCTs were generally considered to be good quality (Jadad score range 3-5). All included trials were double blind with appropriate description of drop out of subjects, although the method of randomisation and blinding was not always reported. The majority of the studies included adult patients with diagnosis of RA based on the ACR 1987 revised classification criteria. All studies included DMARD-IR patients. Although the definition of DMARD-IR varied somewhat between the studies, it was most commonly defined as patients with active disease despite of previous treatment with traditional DMARDs. The traditional DMARD was often specified to be MTX, although in fewer studies it was unspecified. Other definitions included inadequate response to prior DMARDs, or patients who are either intolerant to MTX, or the use of MTX is inappropriate. The TEMPO trial included patients who were non-responders to DMARDs but disqualified patients who had failed MTX treatment [52]. Given this difference, the study was excluded from the network meta-analysis. The definitions of active disease varied in terms of the minimum levels of ESR $(10 \mathrm{~mm} / \mathrm{h}, 28 \mathrm{~mm} / \mathrm{h})$ and CRP $(2 \mathrm{mg} / \mathrm{dl}, 1 \mathrm{mg} / \mathrm{dl}$, $1.5 \mathrm{mg} / \mathrm{dl}, 7 \mathrm{mg} / \mathrm{ml}$ ), as well as in terms of the minimum number of required tender [6-12] and swollen [6-12] joints. Not all studies reported whether RA disease duration and DMARD treatment duration determined eligibility.

In RCTs evaluating the efficacy of biologics in combination with a traditional DMARD, MTX was the background treatment of choice, except for the study by Combe et al. in which sulfasalazine was used $[37,38]$. To allow a valid indirect comparison between treatments with the network meta-analysis, this study was excluded as well. The study by Schiff et al. was also excluded because no results at 24 weeks were provided for the outcomes of interest [48].

Thirteen studies, including ACT-RAY and ADACTA, provided outcome data for pain and PGA $[9,11,36$, 39,41,44,49-51,54,55]. All seventeen studies provided information on HAQ-DI. Eight studies (including ADACTA) provided information on the SF36 PFS [9,40,44,47,49-51], but 2 of these studies (ADACTA and Matthias 2000) could not be used for the network meta-analysis because these studies could not be linked to the network of RCTs. The number of studies providing 


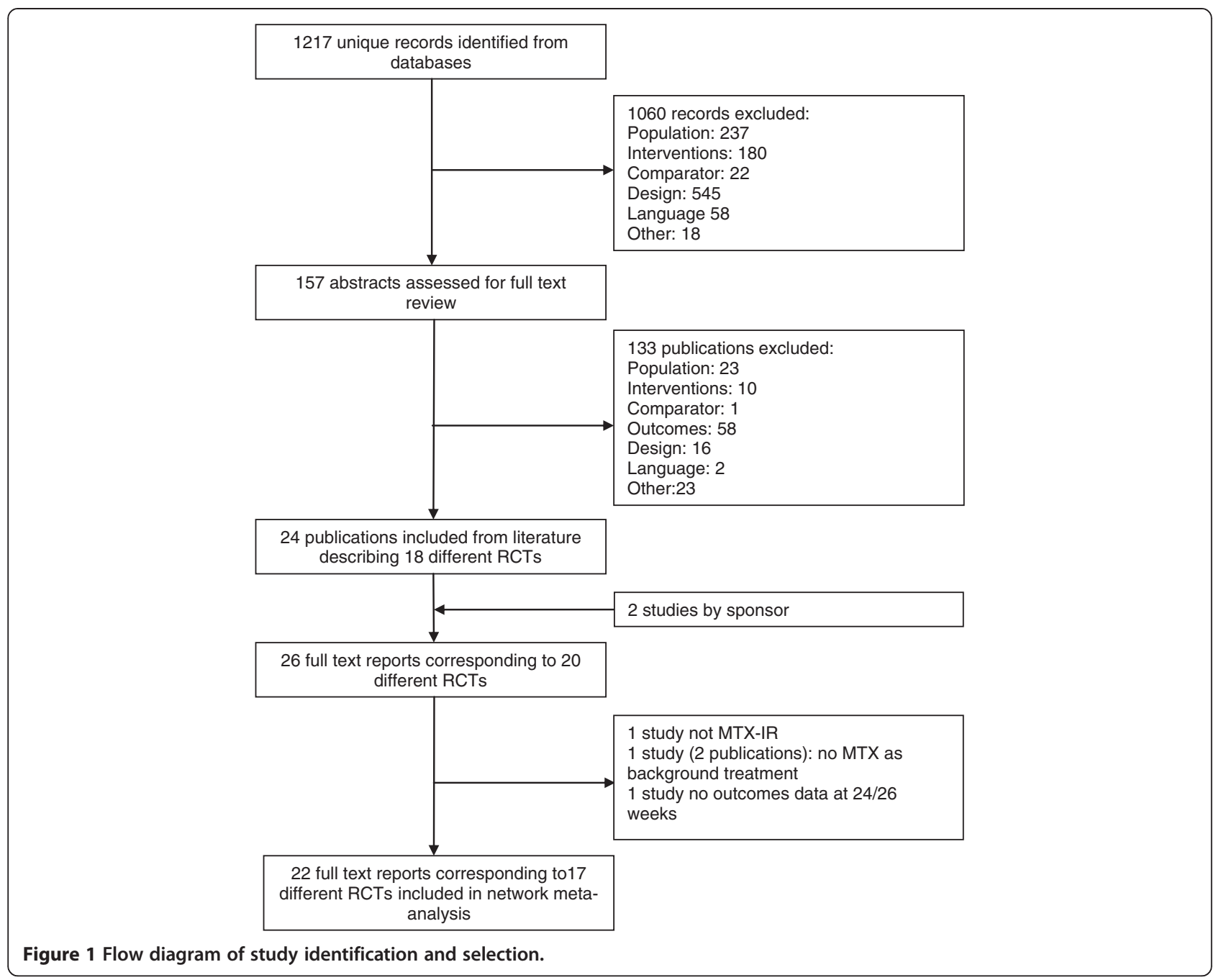

information on the SF36 MCS was too limited to allow network meta-analysis. Nine studies (including ADACTA) reported fatigue as an outcome measure, but given differences in the instruments used (i.e. Functional Assessment of Chronic Illness Therapy-Fatigue (FACIT-F), Fatigue Assessment Scale (FAS), and Fatigue VAS) a network meta-analysis was not considered feasible $[39,40,43,47,49-51,56]$.
In Figure 2 the network of the 17 RCTs is presented where each line between nodes reflects the available direct comparisons. By means of network metaanalysis a treatment effect of each intervention relative to another that is part of the same network can be obtained.

Table 1 provides information on the study and patient characteristics of the 17 RCTs used for the network

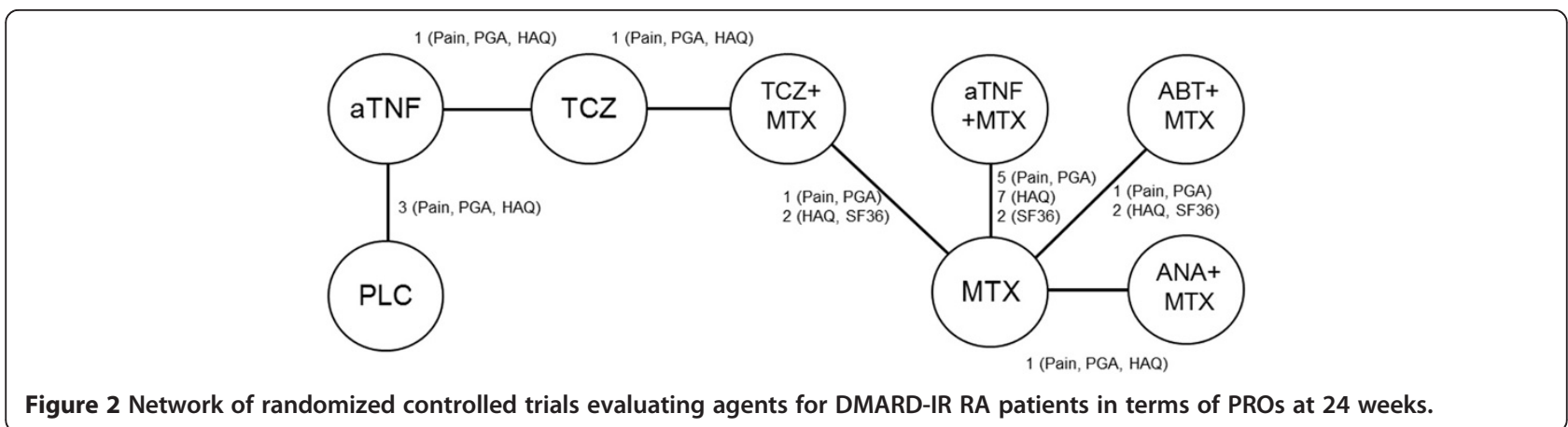


Table 1 Study and patient baseline characteristics of studies included in the network meta-analysis

\begin{tabular}{|c|c|c|c|c|c|c|c|c|c|c|}
\hline Study & Interventions & $\begin{array}{l}\text { Number of } \\
\text { patients }\end{array}$ & $\begin{array}{c}\text { AGE } \\
\text { (years) }\end{array}$ & Female (\%) & $\begin{array}{c}\text { Disease } \\
\text { duration } \\
\text { (years) }\end{array}$ & $\begin{array}{c}\text { SJC } \\
(0-66)\end{array}$ & $\begin{array}{c}\text { TJC } \\
(0-68)\end{array}$ & $\begin{array}{l}\text { ESR } \\
(\mathrm{mm} / \mathrm{hr})\end{array}$ & $\begin{array}{l}\mathrm{CRP} \\
(\mathrm{mg} / \mathrm{L})\end{array}$ & $\begin{array}{c}\mathrm{RF}+\mathrm{ve} \\
\text { number (\%) }\end{array}$ \\
\hline \multirow{2}{*}{ Kremer [44] } & ABT $10 \mathrm{mg} / \mathrm{kg}$ Q4W + MTX & 115 & 56 & 75 & 10 & 21.3 & 30.8 & NR & 29 & 90 \\
\hline & Placebo + MTX & 119 & 55 & 66 & 9 & 21.8 & 29.2 & NR & 32 & 90 \\
\hline \multirow{2}{*}{$\begin{array}{l}\text { Kremer [43], } \\
\text { Russell [47] }\end{array}$} & ABT $10 \mathrm{mg} / \mathrm{kg}$ Q4W + MTX & 433 & 52 & 78 & 9 & 21.4 & 31 & NR & 33 & 82 \\
\hline & Placebo + MTX & 219 & 50 & 82 & 9 & 22.1 & 32.3 & $N R$ & 28 & 79 \\
\hline \multirow{2}{*}{ Cohen [36] } & ANA $100 \mathrm{mg}$ QD + MTX & 250 & 56 & 79 & 11 & 20.1 & 26.8 & 41.5 & 27 & 76 \\
\hline & Placebo + MTX & 251 & 57 & 75 & 10 & 20 & 24.5 & 42.9 & 26 & 78 \\
\hline \multirow{2}{*}{$\begin{array}{l}\text { Maini [46], Lipsky } \\
\text { [45] (ATTRACT) }\end{array}$} & IFX 3 mg/kg Q8W + MTX & 86 & 54 & 81 & 10 & 22 & 32 & 49 & 39 & 84 \\
\hline & Placebo + MTX & 88 & 51 & 80 & 11 & 21 & 31 & 49 & 40 & 77 \\
\hline \multirow{2}{*}{$\begin{array}{l}\text { Keystone [41], } \\
\text { Yount [56] }\end{array}$} & ADA 40 mg QOW + MTX & 207 & 56 & 76 & 11 & 19.3 & 27.3 & NR & 18 & 82 \\
\hline & Placebo + MTX & 200 & 56 & 73 & 11 & 19 & 28.1 & NR & 18 & 90 \\
\hline \multirow{2}{*}{$\begin{array}{l}\text { Weinblatt [54], Yount } \\
\text { [56] (ARMADA) }\end{array}$} & ADA 40 mg QOW + MTX & 67 & 57 & 75 & 12 & 17.3 & 28 & NR & 21 & NR \\
\hline & Placebo + MTX & 62 & 56 & 82 & 11 & 16.9 & 28.7 & NR & 31 & NR \\
\hline \multirow{2}{*}{ Van de Putte [11] } & ADA 40 mg QOW & 113 & 53 & 80 & 11 & 20.5 & 33.7 & 55.8 & 52.6 & 80 \\
\hline & Placebo & 110 & 54 & 77 & 12 & 19.8 & 35.5 & 56.1 & 57 & 82 \\
\hline \multirow{2}{*}{ Strand [51], (RAPID 1) } & CTZ 200 mg QOW + MTX & 393 & 51 & 82 & 6 & $9.9^{M}$ & $12.4^{M}$ & $43.5^{M}$ & $16^{M}$ & 80 \\
\hline & Placebo + MTX & 199 & 52 & 84 & 6 & $9.7^{M}$ & $13^{M}$ & $45^{M}$ & $16^{M}$ & 83 \\
\hline \multirow{2}{*}{$\begin{array}{l}\text { Smolen [50], Strand } \\
\text { [52], (RAPID 2) }\end{array}$} & CTZ 200 mg QOW + MTX & 246 & 52 & 84 & 6 & 20.5 & 30.1 & 43.7 & 14.2 & 78 \\
\hline & Placebo + MTX & 127 & 52 & 84 & 6 & 21.9 & 30.4 & 40.8 & 13.5 & 78 \\
\hline \multirow{2}{*}{$\begin{array}{l}\text { Fleischmann [39] } \\
\text { (FAST4WARD) }\end{array}$} & CTZ 400 mg Q4W & 111 & 53 & 78 & 9 & 21.2 & 29.6 & 30.9 & 11.6 & 100 \\
\hline & Placebo & 109 & 55 & 89 & 10 & 19.9 & 28.3 & 35.6 & 11.3 & 100 \\
\hline \multirow{2}{*}{ Weinblatt [55] } & ETN 25 mg BW + MTX & 59 & 48 & 90 & 13 & 20 & 28 & 25 & 22 & 84 \\
\hline & Placebo + MTX & 30 & 53 & 73 & 13 & 17 & 28 & 36 & 26 & 90 \\
\hline \multirow{2}{*}{$\begin{array}{l}\text { Moreland [10], } \\
\text { Mathias [9] }\end{array}$} & ETN $25 \mathrm{mg}$ BW & 78 & 53 & 74 & 11 & 25 & 33 & 35 & 47 & 79 \\
\hline & Placebo & 80 & 51 & 76 & 12 & 25 & 35 & 39 & 41 & 79 \\
\hline \multirow{2}{*}{$\begin{array}{l}\text { Keystone [42] } \\
\text { (GO-FORWARD) }\end{array}$} & GLB 50 mg Q4W + MTX & 89 & $52^{M}$ & 81 & $4.5^{\mathrm{M}}$ & $13^{M}$ & $26^{M}$ & NR & $10^{\mathrm{M}}$ & 81 \\
\hline & Placebo + MTX & 133 & $52^{M}$ & 82 & $6.5^{\mathrm{M}}$ & $12^{M}$ & $21^{\mathrm{M}}$ & NR & $8^{M}$ & 81 \\
\hline \multirow{2}{*}{$\begin{array}{l}\text { Genovese [40] } \\
\text { (TOWARD) }\end{array}$} & TCZ 8 mg/kg Q4W + MTX & 803 & 53 & 81 & 10 & 19.7 & 30.1 & 48.2 & 26 & NR \\
\hline & Placebo + MTX & 413 & 54 & 84 & 10 & 18.7 & 29.1 & 49.2 & 26 & NR \\
\hline \multirow{2}{*}{ Smolen [49] (OPTION) } & TCZ 8 mg/kg Q4W + MTX & 205 & 51 & $N R$ & 8 & 19.5 & 31.9 & 51.2 & 26 & 83 \\
\hline & Placebo + MTX & 204 & 51 & NR & 8 & 20.7 & 32.8 & 49.7 & 24 & 71 \\
\hline \multirow{2}{*}{ ACT-RAY } & TCZ 8 mg/kg Q4W + MTX & 277 & 53 & 81.9 & 8.2 & 14.4 & 25.8 & 39.9 & NR & NR \\
\hline & TCZ 8 mg/kg Q4W & 276 & 53.6 & 78.6 & 8.3 & 15.3 & 26.6 & 39.6 & NR & NR \\
\hline \multirow{2}{*}{ ADACTA } & TCZ 8 mg/kg & 163 & 54.4 & 79 & 7.3 & 11.3 & 15.9 & 50.5 & 26 & NR \\
\hline & ADA $40 \mathrm{mg}$ & 162 & 53.3 & 82 & 6.3 & 12.4 & 16.5 & 45.5 & 25 & $N R$ \\
\hline
\end{tabular}

$\mathrm{M}=$ median; $\mathrm{NR}=$ not reported; $\mathrm{SJC}=$ swollen joint count; $\mathrm{TJC}=$ tender joint count; $\mathrm{ESR}=$ erythrocyte sedimentation rate; $\mathrm{CRP}=\mathrm{C}$-reactive protein; $\mathrm{RF}+\mathrm{ve}=$ Rheumatoid factor positive $\mathrm{ABT}=$ abatacept; $\mathrm{ANA}=$ anakinra; IFX = infliximab; $\mathrm{ADA}=$ adalimumab; $\mathrm{CTZ}=$ certolizumab pegol; $\mathrm{ETN}=$ etanercept; $\mathrm{GLB}$ = golimumab; $\mathrm{TCZ}$ = tocilizumab; $\mathrm{MTX}=$ methotrexate.

meta-analysis. The mean age in the study arms ranged from 48 to 57 . Female patients were predominant; the proportion of women in the study arms ranged from $66 \%$ to $90 \%$. Disease duration ranged from 4.5 to 13 years, swollen joint count ranged from 11.3 to 21.9, and tender joint count ranged from 13 to 35.5. The reported ESR ranged from 25 to $56.1 \mathrm{~mm} / 1 \mathrm{hr}$, CRP varied between 8 and 52.6, and rheumatoid factor positivity ranged from $77 \%$ to $100 \%$. Despite some variation in patient characteristics across studies (i.e. duration of disease, lower swollen and tender joint count, and lower CRP), there were no observed systematic differences across the different types of direct comparisons, indicating the feasibility of the network meta-analysis. 


\section{Monotherapy}

In Tables 2, 3, 4 and 5 the results of the network metaanalysis are presented. Each cell presents the difference in change from baseline for the outcome of interest 24 weeks with the intervention (in the rows) relative to a comparator (in the column). Individual study results are provided in Additional file 1: Table S1.

Both aTNF $(-20.2,-17.4,-0.37)$ and tocilizumab $(-31.3,-27.7,-0.53)$ as monotherapy demonstrated greater reductions in pain, self-reported disease activity (PGA), and HAQ-DI scores than placebo. These improvements over placebo were larger than the MCID for each endpoint.

Tocilizumab monotherapy showed greater improvements in pain $(-11.1 ; 95 \%$ CrI $-21.3,-0.1)$ than aTNF as monotherapy, and can be expected to be more efficacious in terms of PGA as well $(-10.3,95 \% \mathrm{CrI}-20.4,0.8$; probability better $=97 \%$ ). Tocilizumab was at least as efficacious as aTNF agents in HAQ-DI improvements $(-0.16$; $95 \%$ CrI -0.37 , 0.05; probability better $=94 \%)$.

In Figure 3 the expected reduction in pain, PGA and HAQ-DI for each treatment as monotherapy is presented. Given the available studies, no comparison of SF36 for the biologics as monotherapy was possible.

\section{Treatment in combination with methotrexate}

aTNF $(-17.9,-19.1)$, abatacept $(-23.0,-13.6)$ and tocilizumab $(-16.0,-15.1)$ in combination with MTX showed comparable reductions in pain and PGA relative to MTX in this DMARD-IR population (Tables 2 and 3). These improvements over MTX are expected to be greater than the MCID. The reduction in pain and PGA with anakinra $(-7.3,-8.7)$ was smaller.

Regarding HAQ-DI, the greatest improvements over MTX can be expected with aTNF $(-0.30)$ and tocilizumab $(-0.27)$, both clinically meaningful, followed by abatacept $(-0.21)$ and anakinra $(-0.11)$ (Table 4). Improvements in physical health according to the SF36-PCS with abatacept, aTNF and tocilizumab were comparable (Table 5).

\section{Comparison of monotherapy and treatment in combination with methotrexate}

There is a $93 \%$ and $96 \%$ probability that aTNF in combination with MTX results in a greater reduction in pain (-12.4) and PGA (-16.1) than aTNF as monotherapy. These differences are expected to be greater than the MCID. For HAQ-DI there is a $92 \%$ chance that aTNF with MTX is more efficacious than aTNF as monotherapy $(-0.21)$. For tocilizumab however, the improvement in pain, PGA, and HAQ-DI with and without MTX was comparable at 24 weeks.

Figure 4 presents the probability that each intervention is ranked as $1^{\text {st }}, 2^{\text {nd }}, 3^{\text {rd }}$ etc. out of all interventions compared for each outcome based on estimated treatment effects and associated uncertainty. These rankograms summarize the available evidence and translate this into measures of decision uncertainty. For example, given the findings in Table 3 there is a $60 \%$ probability that aTNFs in combination with MTX result in the greatest PGA improvements, whereas there is $<1 \%$ probability with aTNF as monotherapy being the best. With aTNF there is $\sim 40 \%$ probability that these treatments as monotherapy rank 6 out of all 8 interventions. The 'shape' (or distribution) of these rankograms give an idea how well the different interventions are doing. The more the distribution is shifted to the left, the more efficacious the intervention is relative to its competitors. For pain, PGA, and HAQ-DI it can be observed that the rankograms for tocilizumab as monotherapy and in combination with MTX are comparable, whereas the rankograms for aTNF as monotherapy and aTNF in combination with MTX are at opposite ends of the spectrum: tocilizumab as monotherapy and in combination with MTX have a comparable efficacy, whereas aTNF as monotherapy is less efficacious than aTNF with MTX, which is consistent for the three PROs.

\section{Discussion}

RA is a disease that results in a considerable burden for patients due to pain and functional disability [1]. Hence, in addition to effectively treating joint inflammation and reducing the rate of joint deterioration, the aim of treatment is to improve quality of life as well. Since the patient's perspective on disease outcomes can be different from the physician's perspective, and the impact of disease on everyday life can only be assessed by the patients themselves, the evaluation of efficacy of interventions for RA should also include PROs. In fact, it has been demonstrated that PROs provide a better discrimination of the impact of treatment effects on symptoms than physician-reported outcomes [57-59].

The objective of this study was to compare the efficacy of different classes of biologic treatments with or without MTX in terms of pain, self-reported disease activity, functional ability, physical and mental health (SF-36) and fatigue among DMARD-IR RA patients. Biologic agents in combination with MTX and as monotherapy were evaluated simultaneously as part of one network of RCTs by means of a network meta-analysis and could therefore be indirectly compared. Both aTNF and tocilizumab as monotherapy demonstrated greater reductions in pain, self-reported disease activity (PGA), and functional ability (HAQ-DI) than placebo. However, improvements with tocilizumab monotherapy were greater than aTNF monotherapy in terms of pain and self-reported disease activity. Tocilizumab was at least as efficacious as aTNF regarding functional ability 
Table 2 Treatment effects for all contrast in terms of pain (pain VAS) along with $95 \%$ credible interval and probability that treatment is better than the comparator

\begin{tabular}{|c|c|c|c|c|c|c|c|c|c|}
\hline \multirow{2}{*}{ Intervention } & & \multicolumn{8}{|c|}{ Comparator } \\
\hline & & Placebo & MTX & aTNF & Tocilizumab & aTNF + MTX & Abatacept + MTX & Anakinra + MTX & Tocilizumab + MTX \\
\hline \multirow{3}{*}{ Placebo } & Estimate & 0 & 14.71 & 20.17 & 31.28 & 32.53 & 37.63 & 22.00 & 30.71 \\
\hline & $95 \% \mathrm{Crl}$ & & $(-3.85,33.43)$ & $(12.33,29.73)$ & $(18.69,45.21)$ & $(13.46,52.09)$ & $(6.71,67.22)$ & $(0.86,42.52)$ & $(15.14,46.97)$ \\
\hline & $\mathrm{P}$ (better) & & $5 \%$ & $<1 \%$ & $<1 \%$ & $<1 \%$ & $1 \%$ & $2 \%$ & $<1 \%$ \\
\hline \multirow{3}{*}{ MTX } & Estimate & -14.71 & 0 & 5.42 & 16.55 & 17.85 & 22.98 & 7.29 & 15.97 \\
\hline & $95 \% \mathrm{Crl}$ & $(-33.43,3.85)$ & & $(-10.37,24.07)$ & $(3.81,31.31)$ & $(13.02,23.08)$ & $(-1.54,47.31)$ & $(-2.54,16.69)$ & $(6.26,26.34)$ \\
\hline & P(better) & $95 \%$ & & $22 \%$ & $1 \%$ & $<1 \%$ & $3 \%$ & $5 \%$ & $<1 \%$ \\
\hline \multirow{3}{*}{ aTNF } & Estimate & -20.17 & -5.42 & 0 & 11.09 & 12.40 & 17.27 & 1.84 & 10.60 \\
\hline & $95 \% \mathrm{Crl}$ & $(-29.73,-12.33)$ & $(-24.07,10.37)$ & & $(0.09,21.3)$ & $(-6.63,29.01)$ & $(-13.17,45.84)$ & $(-19.57,19.71)$ & $(-4.53,23.59)$ \\
\hline & P(better) & $>99 \%$ & $78 \%$ & & $2 \%$ & $7 \%$ & $12 \%$ & $40 \%$ & $6 \%$ \\
\hline \multirow{3}{*}{ Tocilizumab } & Estimate & -31.28 & -16.55 & -11.09 & 0 & 1.30 & 6.23 & -9.29 & -0.56 \\
\hline & $95 \% \mathrm{Crl}$ & $(-45.21,-18.69)$ & $(-31.31,-3.81)$ & $(-21.3,-0.09)$ & & $(-13.98,15.15)$ & $(-21.98,33.48)$ & $(-27.22,6.19)$ & $(-10.64,8.41)$ \\
\hline & $\mathrm{P}$ (better) & $>99 \%$ & $99 \%$ & $98 \%$ & & $41 \%$ & $33 \%$ & $91 \%$ & $56 \%$ \\
\hline \multirow{3}{*}{ aTNF + MTX } & Estimate & -32.53 & -17.85 & -12.40 & -1.30 & 0 & 5.06 & -10.60 & -1.85 \\
\hline & $95 \% \mathrm{Crl}$ & $(-52.09,-13.46)$ & $(-23.08,-13.02)$ & $(-29.01,6.63)$ & $(-15.15,13.98)$ & & $(-19.92,29.83)$ & $(-21.84,-0.05)$ & $(-12.93,9.48)$ \\
\hline & P(better) & $>99 \%$ & $>99 \%$ & $93 \%$ & $59 \%$ & & $35 \%$ & $98 \%$ & $65 \%$ \\
\hline \multirow{3}{*}{ Abatacept + MTX } & Estimate & -37.63 & -22.98 & -17.27 & -6.23 & -5.06 & 0 & -15.61 & -6.93 \\
\hline & $95 \% \mathrm{Crl}$ & $(-67.22,-6.71)$ & $(-47.31,1.54)$ & $(-45.84,13.17)$ & $(-33.48,21.98)$ & $(-29.83,19.92)$ & & $(-42.08,10.48)$ & $(-33.04,19.51)$ \\
\hline & P(better) & $99 \%$ & $97 \%$ & $88 \%$ & $67 \%$ & $65 \%$ & & $89 \%$ & $70 \%$ \\
\hline \multirow{3}{*}{ Anakinra + MTX } & Estimate & -22.00 & -7.29 & -1.84 & 9.29 & 10.60 & 15.61 & 0 & 8.73 \\
\hline & $95 \% \mathrm{Crl}$ & $(-42.52,-0.86)$ & $(-16.69,2.54)$ & $(-19.71,19.57)$ & $(-6.19,27.22)$ & $(0.05,21.84)$ & $(-10.48,42.08)$ & & $(-4.56,23.05)$ \\
\hline & P(better) & $98 \%$ & $95 \%$ & $60 \%$ & $9 \%$ & $2 \%$ & $11 \%$ & & $7 \%$ \\
\hline \multirow{3}{*}{ Tocilizumab + MTX } & Estimate & -30.71 & -15.97 & -10.60 & 0.56 & 1.85 & 6.93 & -8.73 & 0 \\
\hline & $95 \% \mathrm{Crl}$ & $(-46.97,-15.14)$ & $(-26.34,-6.26)$ & $(-23.59,4.53)$ & $(-8.41,10.64)$ & $(-9.48,12.93)$ & $(-19.51,33.04)$ & $(-23.05,4.56)$ & \\
\hline & P(better) & $>99 \%$ & $>99 \%$ & $94 \%$ & $44 \%$ & $35 \%$ & $30 \%$ & $93 \%$ & \\
\hline
\end{tabular}

$\mathrm{P}($ better) $=$ Probability that treatment (in row) is showing greater efficacy than comparator (in column); $\mathrm{Crl}=$ credible interval; aTNF = Anti-tumor necrosis factor. 
Table 3 Treatment effects for all contrast in terms of patient global assessment (PGA VAS) along with 95\% credible interval and probability that treatment is better than the comparator

\begin{tabular}{|c|c|c|c|c|c|c|c|c|c|}
\hline \multirow{2}{*}{ Intervention } & & \multicolumn{8}{|c|}{ Comparator } \\
\hline & & Placebo & MTX & aTNF & Tocilizumab & aTNF + MTX & Abatacept + MTX & Anakinra + MTX & Tocilizumab + MTX \\
\hline & Estimate & 0 & 14.32 & 17.35 & 27.69 & 33.49 & 27.98 & 23.04 & 29.43 \\
\hline \multirow[t]{3}{*}{ Placebo } & $95 \% \mathrm{Crl}$ & & $(-4.66,32)$ & $(10.63,25.39)$ & $(15.06,40.53)$ & $(14.01,51.89)$ & $(3.21,50.46)$ & $(2.06,42.8)$ & $(13.49,44.66)$ \\
\hline & P(better) & & $5 \%$ & $<1 \%$ & $<1 \%$ & $<1 \%$ & $2 \%$ & $2 \%$ & $<1 \%$ \\
\hline & Estimate & -14.32 & 0 & 2.91 & 13.22 & 19.05 & 13.62 & 8.72 & 15.06 \\
\hline \multirow[t]{3}{*}{ MTX } & $95 \% \mathrm{Crl}$ & $(-32,4.66)$ & & $(-12.59,21.31)$ & $(0.76,27.44)$ & $(14.36,24.21)$ & $(-1.97,28.4)$ & $(-0.37,17.84)$ & $(5.66,25.14)$ \\
\hline & P(better) & $95 \%$ & & $34 \%$ & $2 \%$ & $<1 \%$ & $4 \%$ & $3 \%$ & $1 \%$ \\
\hline & Estimate & -17.35 & -2.91 & 0 & 10.29 & 16.09 & 10.60 & 5.83 & 12.00 \\
\hline \multirow[t]{3}{*}{ aTNF } & $95 \% \mathrm{Crl}$ & $(-25.39,-10.63)$ & $(-21.31,12.59)$ & & $(-0.8,20.37)$ & $(-2.65,32.53)$ & $(-13.52,31.58)$ & $(-15.01,23.52)$ & $(-2.94,24.98)$ \\
\hline & $\mathrm{P}$ (better) & $>99 \%$ & $66 \%$ & & $3 \%$ & $4 \%$ & $16 \%$ & $23 \%$ & $4 \%$ \\
\hline & Estimate & -27.69 & -13.22 & -10.29 & 0 & 5.76 & 0.27 & -4.46 & 1.71 \\
\hline \multirow[t]{3}{*}{ Tocilizumab } & $95 \% \mathrm{Crl}$ & $(-40.53,-15.06)$ & $(-27.44,-0.76)$ & $(-20.37,0.80)$ & & $(-8.91,19.33)$ & $(-20.68,19.62)$ & $(-21.41,10.72)$ & $(-7.84,10.29)$ \\
\hline & $P($ better) & $>99 \%$ & $98 \%$ & $97 \%$ & & $17 \%$ & $49 \%$ & $77 \%$ & $30 \%$ \\
\hline & Estimate & -33.49 & -19.05 & -16.09 & -5.76 & 0 & -5.40 & -10.34 & -4.00 \\
\hline \multirow[t]{3}{*}{ aTNF + MTX } & $95 \% \mathrm{Crl}$ & $(-51.89,-14.01)$ & $(-24.21,-14.36)$ & $(-32.53,2.65)$ & $(-19.33,8.91)$ & & $(-22,10.07)$ & $(-20.94,-0.25)$ & $(-14.82,6.97)$ \\
\hline & $\mathrm{P}$ (better) & $>99 \%$ & $>99 \%$ & $96 \%$ & $83 \%$ & & $76 \%$ & $98 \%$ & $81 \%$ \\
\hline & Estimate & -27.98 & -13.62 & -10.60 & -0.27 & 5.40 & 0 & -4.86 & 1.39 \\
\hline \multirow[t]{3}{*}{ Abatacept + MTX } & $95 \% \mathrm{Crl}$ & $(-50.46,-3.21)$ & $(-28.4,1.97)$ & $(-31.58,13.52)$ & $(-19.62,20.68)$ & $(-10.07,22)$ & & $(-22.16,13.21)$ & $(-16.06,20.05)$ \\
\hline & $\mathrm{P}$ (better) & $98 \%$ & $96 \%$ & $84 \%$ & $51 \%$ & $24 \%$ & & $71 \%$ & $43 \%$ \\
\hline & Estimate & -23.04 & -8.72 & -5.83 & 4.46 & 10.34 & 4.86 & 0 & 6.30 \\
\hline \multirow[t]{3}{*}{ Anakinra + MTX } & $95 \% \mathrm{Crl}$ & $(-42.8,-2.06)$ & $(-17.84,0.37)$ & $(-23.52,15.01)$ & $(-10.72,21.41)$ & $(0.25,20.94)$ & $(-13.21,22.16)$ & & $(-6.65,20.01)$ \\
\hline & $\mathrm{P}$ (better) & $98 \%$ & $97 \%$ & $77 \%$ & $23 \%$ & $2 \%$ & $29 \%$ & & $12 \%$ \\
\hline & Estimate & -29.43 & -15.06 & -12.00 & -1.71 & 4.00 & -1.39 & -6.30 & 0 \\
\hline \multirow[t]{2}{*}{ Tocilizumab + MTX } & $95 \% \mathrm{Crl}$ & $(-44.66,-13.49)$ & $(-25.14,-5.66)$ & $(-24.98,2.94)$ & $(-10.29,7.84)$ & $(-6.97,14.82)$ & $(-20.05,16.06)$ & $(-20.01,6.65)$ & \\
\hline & P(better) & $>99 \%$ & $99 \%$ & $96 \%$ & $70 \%$ & $19 \%$ & $57 \%$ & $88 \%$ & \\
\hline
\end{tabular}

$\mathrm{P}(\mathrm{better})=$ Probability that treatment (in row) is showing greater efficacy than comparator (in column); $\mathrm{Crl}=$ credible interval; aTNF $=$ Anti-tumor necrosis factor. 
Table 4 Treatment effects for all contrast in terms of HAQ-DI along with $95 \%$ credible interval and probability that treatment is better than the comparator

\begin{tabular}{|c|c|c|c|c|c|c|c|c|c|}
\hline \multirow{2}{*}{ Intervention } & & \multicolumn{8}{|c|}{ Comparator } \\
\hline & & Placebo & MTX & aTNF & Tocilizumab & aTNF + MTX & Abatacept + MTX & Anakinra + MTX & Tocilizumab + MTX \\
\hline & Estimate & 0 & 0.28 & 0.37 & 0.53 & 0.58 & 0.49 & 0.39 & 0.55 \\
\hline \multirow[t]{3}{*}{ Placebo } & $95 \% \mathrm{Crl}$ & & $(-0.05,0.62)$ & $(0.22,0.53)$ & $(0.27,0.79)$ & $(0.24,0.93)$ & $(0.13,0.87)$ & $(0.02,0.77)$ & $(0.25,0.86)$ \\
\hline & $\mathrm{P}$ (better) & & $5 \%$ & $<1 \%$ & $<1 \%$ & $<1 \%$ & $1 \%$ & $2 \%$ & $<1 \%$ \\
\hline & Estimate & -0.28 & 0 & 0.09 & 0.25 & 0.30 & 0.21 & 0.11 & 0.27 \\
\hline \multirow[t]{3}{*}{ MTX } & $95 \% \mathrm{Crl}$ & $(-0.62,0.05)$ & & $(-0.22,0.39)$ & $(0.03,0.47)$ & $(0.22,0.37)$ & $(0.05,0.37)$ & $(-0.05,0.26)$ & $(0.12,0.42)$ \\
\hline & P(better) & $95 \%$ & & $27 \%$ & $2 \%$ & $<1 \%$ & $1 \%$ & $6 \%$ & $<1 \%$ \\
\hline & Estimate & -0.37 & -0.09 & 0 & 0.16 & 0.21 & 0.12 & 0.02 & 0.18 \\
\hline \multirow[t]{3}{*}{ aTNF } & $95 \% \mathrm{Crl}$ & $(-0.53,-0.22)$ & $(-0.39,0.22)$ & & $(-0.05,0.37)$ & $(-0.1,0.52)$ & $(-0.21,0.47)$ & $(-0.32,0.36)$ & $(-0.08,0.44)$ \\
\hline & $\mathrm{P}$ (better) & $>99 \%$ & $73 \%$ & & $6 \%$ & $8 \%$ & $23 \%$ & $46 \%$ & $8 \%$ \\
\hline & Estimate & -0.53 & -0.25 & -0.16 & 0 & 0.05 & -0.04 & -0.14 & 0.02 \\
\hline \multirow[t]{3}{*}{ Tocilizumab } & $95 \% \mathrm{Crl}$ & $(-0.79,-0.27)$ & $(-0.47,-0.03)$ & $(-0.37,0.05)$ & & $(-0.18,0.28)$ & $(-0.3,0.24)$ & $(-0.41,0.13)$ & $(-0.14,0.18)$ \\
\hline & P(better) & $>99 \%$ & $98 \%$ & $94 \%$ & & $32 \%$ & $63 \%$ & $88 \%$ & $39 \%$ \\
\hline & Estimate & -0.58 & -0.30 & -0.21 & -0.05 & 0 & -0.09 & -0.19 & -0.03 \\
\hline \multirow[t]{3}{*}{ aTNF + MTX } & $95 \% \mathrm{Crl}$ & $(-0.93,-0.24)$ & $(-0.37,-0.22)$ & $(-0.52,0.10)$ & $(-0.28,0.18)$ & & $(-0.26,0.09)$ & $(-0.36,-0.02)$ & $(-0.19,0.14)$ \\
\hline & $P($ better $)$ & $>99 \%$ & $>99 \%$ & $92 \%$ & $68 \%$ & & $85 \%$ & $98 \%$ & $65 \%$ \\
\hline & Estimate & -0.49 & -0.21 & -0.12 & 0.04 & 0.09 & 0 & -0.10 & 0.06 \\
\hline \multirow[t]{3}{*}{ Abatacept + MTX } & $95 \% \mathrm{Crl}$ & $(-0.87,-0.13)$ & $(-0.37,-0.05)$ & $(-0.47,0.21)$ & $(-0.24,0.30)$ & $(-0.09,0.26)$ & & $(-0.33,0.12)$ & $(-0.16,0.27)$ \\
\hline & $P($ better $)$ & $99 \%$ & $99 \%$ & $77 \%$ & $37 \%$ & $15 \%$ & & $84 \%$ & $28 \%$ \\
\hline & Estimate & -0.39 & -0.11 & -0.02 & 0.14 & 0.19 & 0.10 & 0 & 0.16 \\
\hline \multirow[t]{3}{*}{ Anakinra + MTX } & $95 \% \mathrm{Crl}$ & $(-0.77,-0.02)$ & $(-0.26,0.05)$ & $(-0.36,0.32)$ & $(-0.13,0.41)$ & $(0.02,0.36)$ & $(-0.12,0.33)$ & & $(-0.06,0.37)$ \\
\hline & P(better) & $98 \%$ & $94 \%$ & $54 \%$ & $12 \%$ & $2 \%$ & $16 \%$ & & $6 \%$ \\
\hline & Estimate & -0.55 & -0.27 & -0.18 & -0.02 & 0.03 & -0.06 & -0.16 & 0 \\
\hline \multirow[t]{2}{*}{ Tocilizumab + MTX } & $95 \% \mathrm{Crl}$ & $(-0.86,-0.25)$ & $(-0.42,-0.12)$ & $(-0.44,0.08)$ & $(-0.18,0.14)$ & $(-0.14,0.19)$ & $(-0.27,0.16)$ & $(-0.37,0.06)$ & \\
\hline & P(better) & $>99 \%$ & $>99 \%$ & $92 \%$ & $61 \%$ & $35 \%$ & $72 \%$ & $94 \%$ & \\
\hline
\end{tabular}

$\mathrm{P}($ better) $=$ Probability that treatment (in row) is showing greater efficacy than comparator (in column); $\mathrm{Crl}=$ credible interval; aTNF = Anti-tumor necrosis factor. 
Table 5 Treatment effects for all contrast in terms of SF36-PCS along with $95 \%$ credible interval and probability that treatment is better than the comparator

\begin{tabular}{|c|c|c|c|c|c|}
\hline \multirow{2}{*}{ Intervention } & & \multicolumn{4}{|c|}{ Comparator } \\
\hline & & MTX & Abatacept + MTX & aTNF + MTX & Tocilizumab + MTX \\
\hline \multirow{3}{*}{ MTX } & Estimate & 0 & -4.18 & -5.24 & -4.58 \\
\hline & $95 \% \mathrm{Crl}$ & & $(-6.07,-2.27)$ & $(-6.33,-4.16)$ & $(-5.9,-3.27)$ \\
\hline & P(better) & & $<1 \%$ & $<1 \%$ & $<1 \%$ \\
\hline \multirow{3}{*}{ Abatacept + MTX } & Estimate & 4.18 & 0 & -1.08 & -0.41 \\
\hline & $95 \% \mathrm{Crl}$ & $(2.27,6.07)$ & & $(-3.25,1.11)$ & $(-2.72,1.87)$ \\
\hline & $\mathrm{P}$ (better) & $>99 \%$ & & $17 \%$ & $36 \%$ \\
\hline \multirow{3}{*}{ aTNF + MTX } & Estimate & 5.24 & 1.08 & 0 & 0.66 \\
\hline & $95 \% \mathrm{Crl}$ & $(4.16,6.33)$ & $(-1.11,3.25)$ & & $(-1.04,2.36)$ \\
\hline & $\mathrm{P}$ (better) & $>99 \%$ & $83 \%$ & & $78 \%$ \\
\hline \multirow{3}{*}{ Tocilizumab + MTX } & Estimate & 4.58 & 0.41 & -0.66 & 0 \\
\hline & $95 \% \mathrm{Crl}$ & $(3.27,5.9)$ & $(-1.87,2.72)$ & $(-2.36,1.04)$ & \\
\hline & $P$ (better) & $>99 \%$ & $64 \%$ & $22 \%$ & \\
\hline
\end{tabular}

$\mathrm{P}($ better $)=$ Probability that treatment (in row) is showing greater efficacy than comparator (in column); Crl=credible interval; aTNF = Anti-tumor necrosis factor.

(HAQ-DI). In combination with MTX, aTNF, abatacept and tocilizumab showed comparable improvements in pain, self-reported disease activity, and physical health as measured with the SF36-PCS component, whereas aTNF and tocilizumab showed the greatest improvements in HAQ-DI. An interesting finding was that aTNFs as monotherapy seem less effective than aTNFs in combination with MTX. With tocilizumab as monotherapy, PROs similar to that of tocilizumab in combination with MTX were observed. The difference between aTNF as monotherapy and aTNF in combination with MTX can be considered clinically meaningful according to the defined MCID for pain $(10 \mathrm{~mm})$, PGA (10 mm) and HAQ-DI (0.22).

In addition to pain, self-reported disease activity, functional ability, and physical health, we aimed to perform an analysis for fatigue as well. Fatigue is common in RA $[60,61]$. Given the differences in fatigue scales used across studies we did not perform a network meta-analysis for this endpoint. However, since fatigue is strongly associated with pain, and secondary associated with disease activity [62], it can be expected to find a similar pattern of efficacy across biologics for fatigue as obtained for pain and PGA.

A limitation of the current analysis is that the study did not explicitly address differences in risk due to adverse events among treatments. However, an analysis of relative short term RCT data would not provide a valid picture of the adverse event risk associated with long-term use of biologics. The evidence of efficacy for all interventions was obtained from RCTs identified by means of a systematic literature review, which is a strength from an internal validity point of view. It is important to realize that the value of randomization holds within trials but not across trials. As such, there is the possibility that differences in study and patients characteristics across studies are modifiers of the treatment effects. This is a source of heterogeneity across studies comparing the same interventions, and a source of bias in the indirect comparison of treatments [29]. There was some variation in duration of disease, lower swollen and tender joint count, and CRP across studies, but we did not observe systematic differences in the distribution of disease duration across different types of direct comparisons. As such, these factors can be a cause of heterogeneity (i.e. variation in true treatment effect across studies within comparison) but are likely not biasing the indirect comparisons. Of course, we can never exclude the possibility of unmeasured differences in patient characteristics across different comparisons.

Although other network meta-analysis of biologic treatments for RA have been published in the past few years [15-22], they focus on clinical outcomes such as the ACR response rates. This is the first network meta-analysis that compares the treatment effects of combination therapy and monotherapy on PROs. This makes it difficult to compare findings, but highlights the value of this review in adding to the evidence base.

In addition to this network meta-analysis of PROs, we recently performed a similar analysis for the ACR 20/50/ 70 response outcomes. ACR response is a summary measure that captures improvement in tender and swollen joint counts, patient and physician global assessment of disease, pain, C-reactive protein, and disability. The findings of that network meta-analysis were comparable, illustrating that there is not only consistency across the different PROs, but all also with the 


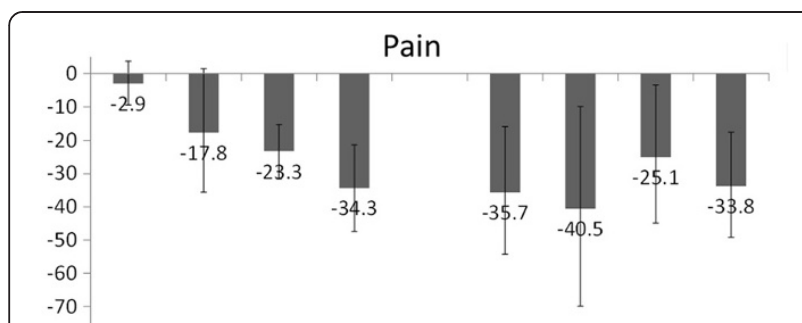

Patient Global Assessment
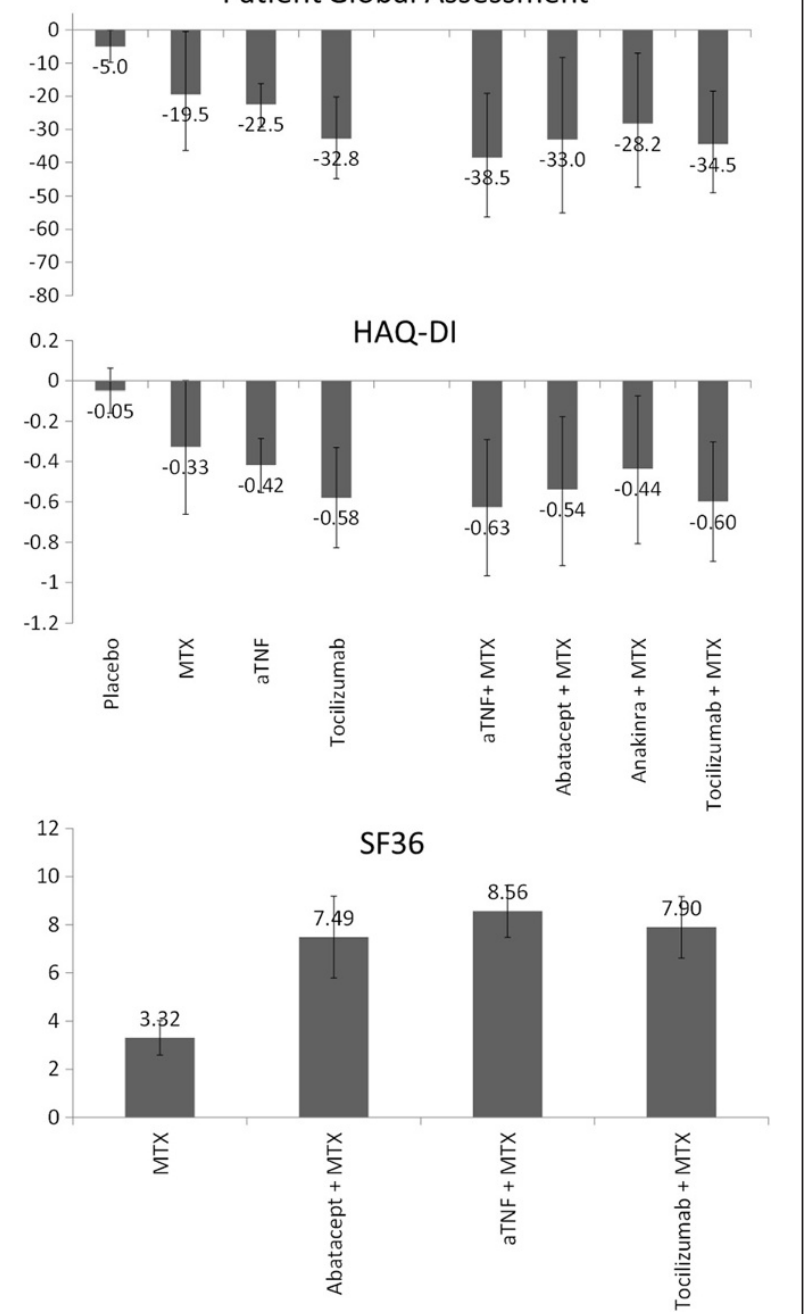

Figure 3 Modeled change in pain, PGA, HAQ-DI and SF36 for different classes of biologic treatments with and without MTX.

ACR responses. With the PRO analyses however, the contrasts in efficacy between aTNF as monotherapy and combination therapy seem even stronger. The clinically meaningful differences in pain, PGA and HAQ-DI between monotherapy and combination therapy can have important clinical implications. In patients unable to tolerate MTX, tocilizumab appears to offer a greater likelihood of PRO improvements than aTNF monotherapy and may represent an attractive option in this population.

\section{Conclusion}

Based on a network meta-analysis involving indirect comparison of trial findings, the following can be concluded for DMARD-IR patients: In monotherapy, tocilizumab was associated with greater improvements in pain and self-reported disease activity (PGA) than aTNF, and is at least as efficacious regarding functional ability (HAQ-DI). The efficacy of aTNF, abatacept and tocilizumab in combination with MTX were comparable. Improvements in pain, self-reported disease activity, and functional ability with tocilizumab as monotherapy were similar to that of tocilizumab with MTX, whereas aTNF as monotherapy was likely to be less efficacious than aTNF with MTX.

\section{Appendix: Search strategy}

The following terms were used to search Medline/ EMBASE in April 2012:

1. "randomized controlled trial".pt.

2. (random\$ or placebo $\$$ or single blind $\$$ or double blind\$ or triple blind\$).ti,ab.

3. (retraction of publication or retracted publication). pt.

4. 1 or 2 or 3

5. (animals not humans).sh.

6. ((comment or editorial or meta-analysis or practice-guideline or review or letter or journal correspondence) not "randomized controlled trial").pt.

7. (random sampl\$ or random digit\$ or random effect $\$$ or random survey or random regression).ti,ab. not "randomized controlled trial".pt.

8. 5 or 6 or 7

9. 4 not 8

10. (random\$ or placebo $\$$ or single blind\$ or double blind\$ or triple blind\$).ti,ab.

11. RETRACTED ARTICLE/

12. 10 or 11

13. (animal\$ not human\$).sh,hw.

14. (book or conference paper or editorial or letter or review).pt. not exp randomized controlled trial/

15. (random sampl\$ or random digit\$ or random effect\$ or random survey or random regression).ti, ab. not exp randomized controlled trial/

16. 13 or 14 or 15

17. 12 not 16

18. 9 or 17

19. Arthritis, Rheumatoid/

20. rheumatoid arthritis.ti,ab.

21. 19 or 20

22. (adalimumab or Humira).ti,ab.

23. (etanercept or Enbrel).ti,ab.

24. (infliximab or Remicade).ti,ab.

25. (golimumab or Simponi or CNTO 148).ti,ab. 


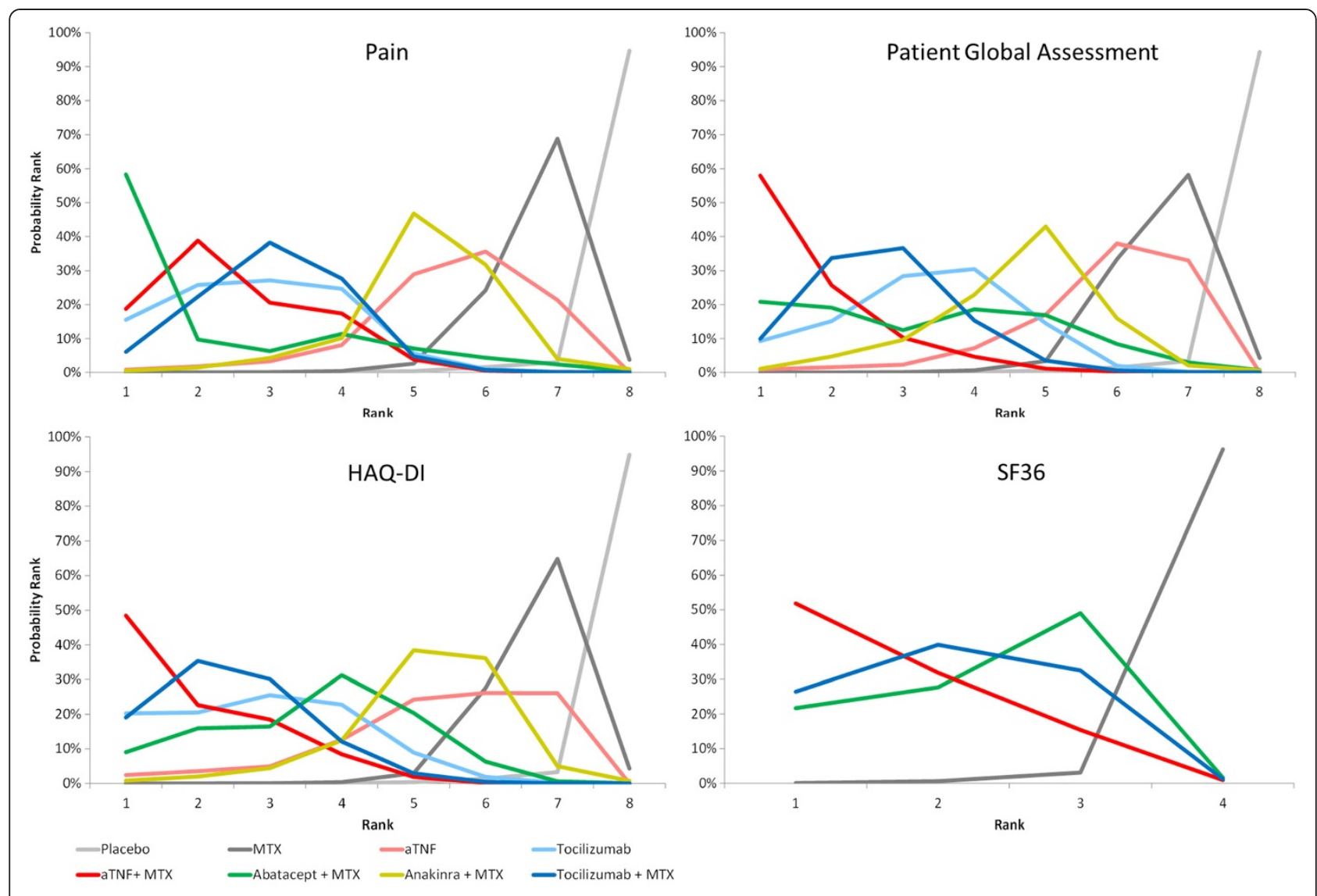

Figure 4 Probability of rank order regarding pain, PGA, HAQ-DI, and SF36 for different classes of biologic treatments with and without MTX.

26. (certolizumab or Cimzia or CDP870).ti,ab.

27. (tocilizumab or Actemra or RoActemra).ti,ab.

28. (rituximab or Rituxan or Mabthera).ti,ab.

29. (abatacept or Orencia or CTLA-4Ig or CTLA-4Ig). ti,ab.

30. (anakinra or Kineret).ti,ab.

31. (tumo?r necrosis factor or TNF).ti,ab.

32. (biologic or biological).ti,ab.

33. 22 or 23 or 24 or 25 or 26 or 27 or 28 or 29 or 30 or 31 or 32

34. 18 and 21 and 33.

The following terms were used to identify trials from the Cochrane Controlled Trials Registry in April 2012:

\#1. MeSH descriptor Arthritis, Rheumatoid, this term only

\#2. rheumatoid arthritis

\#3. (\#1 OR \#2)

\#4. adalimumab or Humira

\#5. etanercept or Enbrel

\#6. infliximab or Remicade

\#7. golimumab or Simponi or CNTO 148

\#8. certolizumab or Cimzia or CDP870
\#9. tocilizumab or Actemra or RoActemra \#10. rituximab or Rituxan or Mabthera \#11. abatacept or Orencia or CTLA-4Ig \#12. anakinra or Kineret \#13. tofacitinib OR tasaocitinib OR CP-690550 \#14. tumo*r necrosis factor OR TNF $\# 15$. biologic or biological \#16. (\#4 OR \#5 OR \#6 OR \#7 OR \#8 OR \#9 OR \#10 OR \#11 OR \#12 OR \#13 OR \#14 OR \#15).

\section{Additional file}

Additional file 1: Table S1. Pain, PGA, HAQ-DI and SF36 at 24 weeks as reported in the individual studies used for the network meta-analysis.

\section{Abbreviations}

aTNF: Tumor necrosis factor blockers; DMARD: Traditional disease-modifying anti-rheumatic drugs; DMARD-IR: Inadequate response to conventional DMARDs; HRQoL: Health related Quality of Life; IL-1: Interleukin-1; IR: Inadequate response; MTX: Methotrexate; PRO: Patient Reported Outcomes; RA: Rheumatoid arthritis; RCT: Randomized controlled trial; HAQ-DI: Health Assessment Questionnaire Disability Index; VAS: Visual analog scale; MCID: Minimum clinically important differences; PCS: Physical health component summary; PGA: Patient's global assessment of disease activity; MCS: Mental health component summary. 


\section{Competing interests}

JP Jansen: Consultant for Genentech; F Buckley: Consultant for Genentech; F Dejonckheere: Employee of Roche; S Ogale: Employee and shareholder of Genentech.

\section{Authors' contributions}

JJ and FB were responsible for design, systematic review, analysis, interpretation, and writing. FD and SO were responsible for design and writing. All authors read and approved the final manuscript.

\section{Author details}

${ }^{1}$ Previously of Mapi Group, Boston, MA, USA. ${ }^{2}$ Tufts University School of Medicine, Boston, MA, USA. 'Mapi Group, 180 Canal Street, Suite 503, Boston, MA 02114, USA. ${ }^{4}$ F. Hoffman-La Roche, Basel, Switzerland. ${ }^{5}$ Genentech, South San Francisco, CA, USA.

Received: 13 January 2014 Accepted: 9 June 2014

Published: 3 July 2014

\section{References}

1. Whalley D, McKenna SP, de Jong Z, van der Heijde D: Quality of life in rheumatoid arthritis. Br J Rheumatol 1997, 36:884-888,

2. Cole JC, Motivala SJ, Khanna D, Lee JY, Paulus HE, Irwin MR: Validation of single-factor structure and scoring protocol for the Health Assessment Questionnaire-Disability Index. Arthritis Rheum 2005, 53:536-542.

3. Saag KG, Teng GG, Patkar NM, Anuntiyo J, Finney C, Curtis JR, Paulus HE, Mudano A, Pisu M, Elkins-Melton M, Outman R, Allison JJ, Suarez Almazor M, Bridges SL Jr, Chatham WW, Hochberg M, MacLean C, Mikuls T, Moreland LW, O'Dell J, Turkiewicz AM, Furst DE: American College of Rheumatology 2008 recommendations for the use of nonbiologic and biologic disease-modifying antirheumatic drugs in rheumatoid arthritis. Arthritis Rheum 2008, 59:762-784.

4. Luqmani R, Hennell S, Estrach C, Basher D, Birrell F, Bosworth A, Burke F, Callaghan C, Candal-Couto J, Fokke C, Goodson N, Homer D, Jackman J, Jeffreson P, Oliver S, Reed M, Sanz L, Stableford Z, Taylor P, Todd N, Warburton L, Washbrook C, Wilkinson M, British Society for Rheumatology, British Health Professionals in Rheumatology Standards, Guidelines and Audit Working Group: British Society for Rheumatology and British Health Professionals in Rheumatology guideline for the management of rheumatoid arthritis (after the first 2 years). Rheumatology (Oxford) 2009, 48:436-439.

5. Felson DT, Anderson JJ, Boers M, Bombardier C, Chernoff M, Fried B, Furst D, Goldsmith C, Kieszak S, Lightfoot R: The American College of Rheumatology preliminary core set of disease activity measures for rheumatoid arthritis clinical trials. The Committee on Outcome Measures in Rheumatoid Arthritis Clinical Trials. Arthritis Rheum 1993, 36:729-740.

6. Ramey DR, Raynauld JP, Fries JF: The health assessment questionnaire 1992: status and review. Arthritis Care Res 1992, 5(3):119-129.

7. Ware JE, Kosinski M, Keller SK: SF-36 Physical and Mental Health Summary Scales: a User's Manual. Boston: New England Medical Center, The Health Institute; 1994

8. Strand V Singh JA: Improved health-related quality of life with effective disease-modifying antirheumatic drugs: evidence from randomized controlled trials. Am J Manag Care 2008, 14:234-254.

9. Mathias SD, Colwell HH, Miller DP, Moreland LW, Buatti M, Wanke L: Health-related quality of life and functional status of patients with rheumatoid arthritis randomly assigned to receive etanercept or placebo. Clin Ther 2000, 22:128-139.

10. Moreland LW, Schiff MH, Baumgartner SW, Tindall EA, Fleischmann RM, Bulpitt KJ, Weaver AL, Keystone EC, Furst DE, Mease PJ, Ruderman EM, Horwitz DA, Arkfeld DG, Garrison L, Burge DJ, Blosch CM, Lange ML, McDonnell ND, Weinblatt ME: Etanercept therapy in rheumatoid arthritis A randomized, controlled trial. Ann Intern Med 1999, 130:478-486.

11. van de Putte $L B$, Atkins C, Malaise M, Sany J, Russell AS, van Riel PL, Settas L, Bijlsma JW, Todesco S, Dougados M, Nash P, Emery P, Walter N, Kaul M, Fischkoff S, Kupper H: Efficacy and safety of adalimumab as monotherapy in patients with rheumatoid arthritis for whom previous disease modifying antirheumatic drug treatment has failed. Ann Rheum Dis 2004, 63:508-516.

12. Listing J, Strangfeld A, Rau R, Kekow J, Gromnica-lhle E, Klopsch T, Demary W, Burmester GR, Zink A: Clinical and functional remission: even though biologics are superior to conventional DMARDs overall success rates remain low-results from RABBIT, the German biologics register. Arthritis Res Ther 2006, 8:R66.
13. Heiberg MS, Koldingsnes W, Mikkelsen K, Rødevand E, Kaufmann C, Mowinckel P, Kvien TK: The comparative one-year performance of anti-tumor necrosis factor alpha drugs in patients with rheumatoid arthritis, psoriatic arthritis, and ankylosing spondylitis: results from a longitudinal, observational, multicenter study. Arthritis Rheum 2008, 59:234-240.

14. Soliman MM, Ashcroft DM, Watson KD, Lunt M, Symmons DP, Hyrich KL: Impact of concomitant use of DMARDs on the persistence with anti-TNF therapies in patients with rheumatoid arthritis: results from the British Society for Rheumatology Biologics Register. Ann Rheum Dis 2011, 70:583-589.

15. Turkstra E, Ng SK, Scuffham PA: A mixed treatment comparison of the short-term efficacy of biologic disease modifying anti-rheumatic drugs in established rheumatoid arthritis. Curr Med Res Opin 2011, 27:1885-1897.

16. Schmitz S, Adams R, Walsh CD, Barry M, Fitzgerald O: A mixed treatment comparison of the efficacy of anti-TNF agents in rheumatoid arthritis for methotrexate non-responders demonstrates differences between treatments: a Bayesian approach. Ann Rheum Dis 2012, 71(2):225-230.

17. Launois R, Avouac B, Berenbaum F, Blin O, Bru I, Fautrel B, Joubert JM, Sibilia J, Combe B: Comparison of certolizumab pegol with other anticytokine agents for treatment of rheumatoid arthritis: a multiple-treatment Bayesian metaanalysis. J Rheumatol 2011, 38:835-845

18. Devine EB, Alfonso-Cristancho R, Sullivan SD: Effectiveness of biologic therapies for rheumatoid arthritis: an indirect comparisons approach. Pharmacotherapy 2011, 31:39-51.

19. Salliot C, Finckh A, Katchamart W, Lu Y, Sun Y, Bombardier C, Keystone E: Indirect comparisons of the efficacy of biological antirheumatic agents in rheumatoid arthritis in patients with an inadequate response to conventional disease-modifying antirheumatic drugs or to an anti-tumour necrosis factor agent: a meta-analysis. Ann Rheum Dis 2011, 70:266-271.

20. Bergman GJ, Hochberg MC, Boers M, Wintfeld N, Kielhorn A, Jansen JP. Indirect comparison of tocilizumab and other biologic agents in patients with rheumatoid arthritis and inadequate response to disease-modifying antirheumatic drugs. Semin Arthritis Rheum 2010, 39:425-441.

21. Singh JA, Christensen R, Wells GA, Suarez-Almazor ME, Buchbinder $R$, Lopez-Olivo MA, Ghogomu ET, Tugwell P: A network meta-analysis of randomized controlled trials of biologics for rheumatoid arthritis: a Cochrane overview. CMAJ 2009, 181:787-796.

22. Nixon RM, Bansback N, Brennan A: Using mixed treatment comparisons and meta-regression to perform indirect comparisons to estimate the efficacy of biologic treatments in rheumatoid arthritis. Stat Med 2007, 26:1237-1254.

23. Jadad A, Moore A, Carroll D, Jenikson C, Reynols J, Gavaghan D, McQuay H: Assessing the quality of reports of randomized clinical trials: is blinding necessary? Control Clin Trials 1996, 17:1-12.

24. Wells G, Li T, Maxwell L, MacLean R, Tugwell P: Determining the minimal clinically important differences in activity, fatigue, and sleep quality in patients with rheumatoid arthritis. J Rheumato/ 2007, 34:280-289.

25. Wells GA, Tugwell P, Kraag GR, Baker PR, Groh J, Redelmeier DA: Minimum important difference between patients with rheumatoid arthritis: the patient's perspective. J Rheumatol 1993, 20:557-560.

26. Farrar JT, Young JP Jr, LaMoreaux L, Werth JL, Poole RM: Clinical importance of changes in chronic pain intensity measured on an 11-point numerical pain rating scale. Pain 2001, 94:149-158.

27. Dworkin RH, Turk DC, Wyrwich KW, Beaton D, Cleeland CS, Farrar JT, Haythornthwaite JA, Jensen MP, Kerns RD, Ader DN, Brandenburg N, Burke LB, Cella D, Chandler J, Cowan P, Dimitrova R, Dionne R, Hertz S, Jadad AR, Katz NP, Kehlet H, Kramer LD, Manning DC, McCormick C, McDermott MP, McQuay HJ, Patel S, Porter L, Quessy S, Rappaport BA, et al: Interpreting the clinical importance of treatment outcomes in chronic pain clinical trials: IMMPACT recommendations. J Pain 2008, 9:105-121.

28. Fries JF, Spitz PW, Young DY: The dimensions of health outcomes: the health assessment questionnaire, disability and pain scales. J Rheumatol 1982, 9:789-793.

29. Jansen JP, Fleurence R, Devine B, Itzler R, Barrett A, Hawkins N, Lee K, Boersma C, Annemans L, Cappelleri JC: Interpreting indirect treatment comparisons and network meta-analysis for health-care decision making: report of the ISPOR Task Force on Indirect Treatment Comparisons Good Research Practices: part 1. Value Health 2011, 14:417-428.

30. Lu G, Ades AE: Combination of direct and indirect evidence in mixed treatment comparisons. Stat Med 2004, 23:3105-3124.

31. Caldwell DM, Ades AE, Higgins JP: Simultaneous comparison of multiple treatments: combining direct and indirect evidence. BMJ 2005, 331:897-900. 
32. Hoaglin DC, Hawkins N, Jansen JP, Scott DA, Itzler R, Cappelleri JC, Boersma C, Thompson D, Larholt KM, Diaz M, Barrett A: Conducting indirect-treatmentcomparison and network-meta-analysis studies: report of the ISPOR Task Force on Indirect Treatment Comparisons Good Research Practices: part 2. Value Health 2011, 14:429-437.

33. Sutton AJ, Abrams KR: Bayesian methods in meta-analysis and evidence synthesis. Stat Methods Med Res 2001, 10:277-303.

34. Spiegelhalter DJ, Best NG, van der Carlin BP, Linde A: Bayesian measures of model complexity and fit. J R Stat Soc 2002, 64:583-639.

35. Spiegelhalter D, Thomas A, Best N, Lunn D: WinBUGS User Manual: Version 1.4. Cambridge: MRC Biostatistics Unit; 2003

36. Cohen SB, Moreland LW, Cush JJ, Greenwald MW, Block S, Shergy WJ, Hanrahan PS, Kraishi MM, Patel A, Sun G, Bear MB, 990145 Study Group: A multicentre, double blind, randomised, placebo controlled trial of anakinra Kineret, a recombinant interleukin 1 receptor antagonist, in patients with rheumatoid arthritis treated with background methotrexate. Ann Rheum Dis 2004, 63:1062-1068.

37. Combe B, Codreanu C, Fiocco U, Gaubitz M, Geusens PP, Kvien TK, Pavelka K, Sambrook PN, Smolen JS, Khandker R, Singh A, Wajdula J, Fatenejad S, Etanercept European Investigators Network: Efficacy, safety and patient-reported outcomes of combination etanercept and sulfasalazine versus etanercept alone in patients with rheumatoid arthritis: a double-blind randomised 2-year study. Ann Rheum Dis 2009, 68:1146-1152.

38. Combe B, Codreanu C, Fiocco U, Gaubitz M, Geusens PP, Kvien TK, Pavelka K, Sambrook PN, Smolen JS, Wajdula J, Fatenejad S, Etanercept European Investigators Network (Etanercept Study 309 Investigators): Etanercept and sulfasalazine, alone and combined, in patients with active rheumatoid arthritis despite receiving sulfasalazine: a double- blind comparison. Ann Rheum Dis 2006, 65:1357-1362.

39. Fleischmann $R$, Vencovsky J, van Vollenhoven RF, Borenstein D, Box J, Coteur G, Goel N, Brezinschek HP, Innes A, Strand V: Efficacy and safety of certolizumab pegol monotherapy every 4 weeks in patients with rheumatoid arthritis failing previous disease-modifying antirheumatic therapy: The FAST4WARD study. Ann Rheum Dis 2009, 68:805-811.

40. Genovese MC, McKay JD, Nasonov EL, Mysler EF, da Silva NA, Alecock E, Woodworth T, Gomez-Reino JJ: Interleukin-6 receptor inhibition with tocilizumab reduces disease activity in rheumatoid arthritis with inadequate response to disease- modifying antirheumatic drugs: the tocilizumab in combination with traditional disease-modifying antirheumatic drug therapy study. Arthritis Rheum 2008, 58:2968-2980.

41. Keystone EC, Kavanaugh AF, Sharp JT, Tannenbaum H, Hua Y, Teoh LS Fischkoff SA, Chartash EK: Radiographic, clinical, and functional outcomes of treatment with adalimumab a human anti-tumor necrosis factor monoclonal antibody in patients with active rheumatoid arthritis receiving concomitant methotrexate therapy: a randomized, placebo-controlled, 52-week trial. Arthritis Rheum 2004, 50:1400-1411.

42. Keystone EC, Genovese MC, Klareskog L, Hsia EC, Hall ST, Miranda PC, Pazdur J, Bae SC, Palmer W, Zrubek J, Wiekowski M, Visvanathan S, Wu Z, Rahman MU, GO-FORWARD Study: Golimumab, a human antibody to tumour necrosis factor \{alpha\} given by monthly subcutaneous injections, in active rheumatoid arthritis despite methotrexate therapy: the GO-FORWARD Study. Ann Rheum Dis 2009, 68:789-796.

43. Kremer JM, Genant HK, Moreland LW, Russell AS, Emery P, Abud-Mendoza C, Szechinski J, Li T, Ge Z, Becker JC, Westhovens R: Effects of abatacept in patients with methotrexate-resistant active rheumatoid arthritis: a randomized trial. Ann Intern Med 2006, 144:865-876.

44. Kremer J, Westhovens R, Leon M, Di Giorgio E, Alten R, Steinfeld S, Russell A, Dougados M, Emery P, Nuamah IF, Williams GR, Becker JC, Hagerty DT, Moreland LW: Treatment of Rheumatoid Arthritis by Selective Inhibition of T-Cell Activation with Fusion Protein CTLA4lg. New Engl J Med 2003, 349:1907-1915.

45. Lipsky PE, van der Heijde DM, St Clair EW, Furst DE, Breedveld FC, Kalden JR, Smolen JS, Weisman M, Emery P, Feldmann M, Harriman GR, Maini RN, Anti-Tumor Necrosis Factor Trial in Rheumatoid Arthritis with Concomitant Therapy Study Group: Infliximab and methotrexate in the treatment of rheumatoid arthritis. Anti-Tumor Necrosis Factor Trial in Rheumatoid Arthritis with Concomitant Therapy Study Group. N Engl J Med 2000, 343(22):1594-1602

46. Maini R, St Clair EW, Breedveld F, Furst D, Kalden J, Weisman M, Smolen J, Emery P, Harriman G, Feldmann M, Lipsky P: Infliximab chimeric anti-tumour necrosis factor alpha monoclonal antibody versus placebo in rheumatoid arthritis patients receiving concomitant methotrexate: a randomised phase III trial ATTRACT Study Group. Lancet 1999, 354:1932-1939.

47. Russell AS, Wallenstein GV, Li T, Martin MC, Maclean R, Blaisdell B, Gajria K, Cole JC, Becker JC, Emery P: Abatacept improves both the physical and mental health of patients with rheumatoid arthritis who have inadequate response to methotrexate treatment. Ann Rheum Dis 2007, 66(2):189-194.

48. Schiff M, Keiserman M, Codding C, Songcharoen S, Berman A, Nayiager S, Saldate C, Li T, Aranda R, Becker JC, Lin C, Cornet PL, Dougados M: Efficacy and safety of abatacept or infliximab vs placebo in ATTEST: a phase III, multi-centre, randomised, double-blind, placebo-controlled study in patients with rheumatoid arthritis and an inadequate response to methotrexate. Ann Rheum Dis 2008, 67:1096-1103.

49. Smolen JS, Beaulieu A, Rubbert-Roth A, Ramos-Remus C, Rovensky J, Alecock E, Woodworth T, Alten R, OPTION Investigators: Effect of interleukin-6 receptor inhibition with tocilizumab in patients with rheumatoid arthritis (OPTION study): a double-blind, placebo-controlled, randomised trial. Lancet 2008, 371:987-997.

50. Smolen J, Landewé RB, Mease P, Brzezicki J, Mason D, Luijtens K van Vollenhoven RF, Kavanaugh A, Schiff M, Burmester GR, Strand V, Vencovsky J, van der Heijde D: Efficacy and safety of certolizumab pegol plus methotrexate in active rheumatoid arthritis: the RAPID 2 study A randomised controlled trial. Ann Rheum Dis 2009, 68:797-804.

51. Strand V, Mease P, Burmester GR, Nikaï E, Coteur G, van Vollenhoven R, Combe B, Keystone EC, Kavanaugh A: Rapid and sustained improvements in health-related quality of life, fatigue, and other patient-reported outcomes in rheumatoid arthritis patients treated with certolizumab pegol plus methotrexate over 1 year: results from the RAPID 1 randomized controlled trial. Arthritis Res Ther 2009, 11(6):R170.

52. Strand V, Smolen JS, van Vollenhoven RF, Mease P, Burmester GR, Hiepe F, Khanna D, Nikaï E, Coteur G, Schiff M: Certolizumab pegol plus methotrexate provides broad relief from the burden of rheumatoid arthritis: analysis of patient-reported outcomes from the RAPID 2 trial. Ann Rheum Dis 2011. 70(6):996-1002.

53. Van der Heijde D, Klareskog L, Singh A, Tornero J, Melo-Gomes J, Codreanu C, Pedersen R, Freundlich B, Fatenejad S: Patient reported outcomes in a trial of combination therapy with etanercept and methotrexate for rheumatoid arthritis: the TEMPO trial. Ann Rheum Dis 2006, 65(3):328-334.

54. Weinblatt M, Keystone EC, Furst DE, Moreland LW, Weisman MH, Birbara CA, Teoh LA, Fischkoff SA, Chartash EK: Adalimumab, a fully human anti-tumor necrosis factor alpha monoclonal antibody, for the treatment of rheumatoid arthritis in patients taking concomitant methotrexate: the ARMADA trial. Arthritis Rheum 2003, 48:35-45.

55. Weinblatt ME, Kremer JM, Bankhurst AD, Bulpitt KJ, Fleischmann RM, Fox RI, Jackson CG, Lange M, Burge DJ: A trial of etanercept, a recombinant tumor necrosis factor receptor:Fc fusion protein, in patients with rheumatoid arthritis receiving methotrexate. N Engl J Med 1999, 340:253-259.

56. Yount S, Sorensen MV, Cella D, Sengupta N, Grober J, Chartash EK Adalimumab plus methotrexate or standard therapy is more effective than methotrexate or standard therapies alone in the treatment of fatigue in patients with active, inadequately treated rheumatoid arthritis. Clin Exp Rheumatol 2007, 25(6):838-846.

57. Tugwell P, Wells G, Strand V, Maetzel A, Bombardier C, Crawford B, Dorrier C, Thompson A: Clinical improvement as reflected in measures of function and health-related quality of life following treatment with leflunomide compared with methotrexate in patients with rheumatoid arthritis: sensitivity and relative efficiency to detect a treatment effect in a twelve-month, placebo-controlled trial. Leflunomide Rheumatoid Arthritis Investigators Group. Arthritis Rheum 2000, 43:506-514.

58. Pincus T, Strand V, Koch G, Amara I, Crawford B, Wolfe F, Cohen S, Felson D: An index of the three core data set patient questionnaire measures distinguishes efficacy of active treatment from that of placebo as effectively as the American College of Rheumatology 20\% response criteria (ACR20) or the Disease Activity Score (DAS) in a rheumatoid arthritis clinical trial. Arthritis Rheum 2003, 48:625-630.

59. Strand V, Cohen S, Crawford B, Smolen JS, Scott DL: Patient-reported outcomes better discriminate active treatment from placebo in randomized controlled trials in rheumatoid arthritis. Rheumatology (Oxford) 2004, 43:640-647. 
60. Wolfe F, Hawley DJ, Wilson K: The prevalence and meaning of fatigue in rheumatic disease. J Rheumatol 1996, 23:1407-1417.

61. Belza BL, Henke CJ, Yelin EH, Epstein WV, Gilliss CL: Correlates of fatigue in older adults with rheumatoid arthritis. Nurs Res 1993, 42:93-99.

62. Pollard LC, Choy EH, Gonzalez J, Khoshaba B, Scott DL: Fatigue in rheumatoid arthritis reflects pain, not disease activity. Rheumatology (Oxford) 2006 45:885-889.

doi:10.1186/1477-7525-12-102

Cite this article as: Jansen et al:: Comparative efficacy of biologics as monotherapy and in combination with methotrexate on patient reported outcomes (PROs) in rheumatoid arthritis patients with an inadequate response to conventional DMARDs - a systematic review and network meta-analysis. Health and Quality of Life Outcomes 2014 12:102.

\section{Submit your next manuscript to BioMed Central and take full advantage of:}

- Convenient online submission

- Thorough peer review

- No space constraints or color figure charges

- Immediate publication on acceptance

- Inclusion in PubMed, CAS, Scopus and Google Scholar

- Research which is freely available for redistribution 